\title{
DIRECTIONALITY AND (UN)NATURAL CLASSES IN SYNCRETISM
}

\author{
MATTHEW BAERMAN \\ Surrey Morphology Group, University of Surrey
}

\begin{abstract}
Syncretism, where a single form corresponds to multiple morphosyntactic functions, is pervasive in languages with inflectional morphology. Its interpretation highlights the contrast between different views of the status of morphology. For some, morphology lacks independent structure, and syncretism reflects the internal structure of morphosyntactic features. For others, morphological structure is autonomous, and syncretism provides direct evidence of this. In this article, I discuss two phenomena which argue for the second view. DIRECTIONAL EFFECTS and UNNATURAL CLASSES of values resist attempts to reduce them to epiphenomena of more general rule types, and require purely morphological devices for their expression. ${ }^{*}$
\end{abstract}

1. Introduction. Consider the two Kashmiri noun paradigms in Table 1. Kashmiri distinguishes four values of the feature case (absolutive, ergative, ablative and dative) and two values of the feature number (singular and plural).

\begin{tabular}{lllllc}
\hline & \multicolumn{2}{c}{$\begin{array}{c}\text { Declension I } \\
\text { 'ass' }\end{array}$} & & \multicolumn{2}{c}{$\begin{array}{c}\text { Declension II } \\
\text { 'tree' }\end{array}$} \\
\hline & SG & PL & & SG & PL \\
ABS & khar & khar & ABS & kul & kul' \\
ERG & kharan & kharav & ERG & kul' & kul'av \\
ABL & khari & kharav & ABL & kuli & kul'av \\
DAT & kharas & kharan & DAT & kulis & kul'an
\end{tabular}

TABLE 1. Kashmiri noun declension (Kachru 1969: 112-16)

The traditional paradigmatic arrangement in Table 1 implies that there are eight distinct inflected forms for each noun. But when we look more closely, we see that there is syncretism in each paradigm -- that is, the same form is repeated in different paradigmatic cells. Thus khar is absolutive singular and absolutive plural, kharan is ergative singular and dative plural, $k u l$ ' is ergative singular and absolutive plural, and both words have forms in - $a v$ for the ergative and ablative plural.

Such graphic representations of paradigms result from an analytical compromise, motivated by the desire for a minimal repertory of morphosyntactic feature values. On the one hand it is the morphological evidence of distinct forms which determines the repertory of

\footnotetext{
* I'd like to thank all the people who have provided helpful comments on this paper in its various versions, both written and oral: Jim Blevins, Jonathan Bobaljik, Dunstan Brown, Andrew Carstairs-McCarthy, Greville Corbett, Roger Evans, Gerald Gazdar, Martin Haspelmath, Louisa Sadler, Andrew Spencer and Greg Stump, as well as editor Brian Joseph and the anonymous reviewers. The research reported here was supported by the Economic and Social Research Council (United Kingdom) under grant number R000237939; their support is gratefully acknowledged.
} 
features. On the other hand, some morphological evidence is overlooked (for example, that there seems to be a single form kharav, but it does not have a single morphosyntactic description). This is the price paid for a compact, manageable system of morphosyntactic features. The practical advantages of such an approach are obvious, as anyone who has leafed through a Latin primer can attest: the varied patterns of case syncretism, richer even than what is found in Kashmiri, can be ignored in the in the account of syntactic rules. But there remains an uneasy discrepancy between the demands of a syntactic description and the morphological facts.

Nor can this discrepancy be easily ignored, since syncretism is endemic in inflectional systems: controlled cross-linguistic studies have shown that case syncretism is found in more than half ( 40 out of 73 ) of the languages which mark case inflectionally (Baerman and Brown in press a), and syncretism of subject person marking on verbs is found in roughly two-thirds (60 out of 140) (Baerman and Brown in press b). It is fair to say that, if a language has inflectional morphology, it is likely to display syncretism, with case, person and gender being the most typically affected features.

Within morphological theory, inflectional syncretism is a long-standing theme (see, for example, the on-line bibliography in Baerman (2002)). Broadly speaking, the theoretical interest lies in what it can tell us both about feature structure and about morphological operations. On the one hand, we might assume that a single form corresponds to a single meaning (a principle which, in Anttila's (1972: 107) words, 'is as old as European linguistics'). This would mean enriching our model of feature structure, e.g. by supposing that the case values in Table 1 are actually compounds of smaller subvalues, which parcel off groups of cases into natural classes. On the other hand, we might content ourselves with the flat feature structure in Table 1, in which case it is up to some purely morphological principle to account for the syncretism between paradigmatic cells. The choice between these two approaches has ramifications that reach beyond morphological theory: each provides syntactic theory with a different repertory of morphosyntactic features to work with.

Since the publication of Stump (2001), debate on this topic has intensified, centering on the tripartite model of syncretism he presents. His three types of syncretism are illustrated below with examples drawn from the paradigms in Table 1. (For the sake of transparency, Stump's rather complex vocabulary of formal representation has been simplified.)

UNSTIPULATED SYNCRETISM occurs where the values involved form a natural class, so that the syncretism results from underspecification, without any further devices. For example, the declension I form khar involves syncretism of all of the paradigmatic cells which include the value absolutive in their description, namely absolutive singular and absolutive plural. Absolutive defines a natural class uniting these two cells. The syncretism will automatically result from a morphological description that invokes only this shared value, without any reference to number; thus, absolutive $=k h a r$.

SYMMETRICAL SYNCRETISM occurs where the syncretized values do not constitute a natural class. The declension I form kharav is good example, because in Stump's model, where feature values have no internal structure, ergative plural and ablative plural do not form a natural class (the smallest natural class that would contain them would be the set of all plural forms). Thus, we can simply stipulate that ergative plural and ablative plural together form a class, and say that this class has the form kharav.

DIRECTIONAL SYNCRETISM likewise involves the stipulation of class membership, but exhibits directional effects, that is, it looks as if the form 'belongs' to one of the component values, and is 'borrowed' by the other value. For example, the dative plural 
ending is -an for all noun declension classes in Kashmiri; in declension I, the ergative singular ending is also - an. This could be described using a directional rule by stating that the dative plural ending is -an for all nouns, and that, in declension I, the ergative singular has the same form as the dative plural. Directional rules are most familiar under the name 'rules of referral', introduced by Zwicky (1985); Carstairs (1987) uses the term 'take-overs'.

This framework has prompted a number of critics, who argue that this wealth of descriptive devices is unnecessary, and that at least one of these three devices should be eliminated. The objections revolve around two points:

FORMAL ECONOMY. There is considerable overlap in range of effects produced by these three devices. For example, the form khar, used above to illustrate unstipulated syncretism, could just as well be treated as symmetrical syncretism (by stipulating that absolutive singular and absolutive plural form a class, whose form is khar) or directional syncretism (by stipulating that the absolutive plural takes the form of the absolutive singular, which is khar). All else being equal, we should eliminate superfluous formal machinery. Since we can hardly eliminate the notion of classes (be they natural or unnatural) from a linguistic analysis, it is directional rules which should be rejected (Zwicky 2000, Wunderlich forthcoming). Directional effects are a merely surface phenomenon, and do not require a separate descriptive device. (Zwicky (2000) goes even further, and rejects the notion of unstipulated syncretism, arguing that natural classes are themselves the product of a prior stage of essentially stipulative analysis.)

RESTRICTIVENESS. Symmetrical syncretism and directional syncretism both involve stipulating relationships within an inflectional paradigm that are independent from feature structure -- that is, independent from meaning or function. Thus, in principle, anything could be syncretic with anything. A model based entirely on unstipulated syncretism would be more restrictive, in that syncretism would be constrained by feature structure. All else being equal, we should prefer the more restrictive model. Such an assessment is apparent in a number of recent works (Müller forthcoming, Bobaljik 2002, Noyer 1998, Carstairs-McCarthy 1998). In fact, it is probably safe to say that most work on syncretism takes this vantage point, in that explanation is typically sought in some aspect of feature structure.

The insightfulness of the current debate is limited by some questions, both formal and empirical, that have not received sufficient attention. Formally, although the question of restrictiveness is often raised, there is a dearth of precise statements about what can and cannot be described within any given model. Empirically, there is a range of phenomena which has simply not been considered. Below, I clarify what the descriptive potential of the different devices is, and show that the facts require a robust model of inflectional morphology, containing both directional rules and unnatural classes.

2. SYSTEMATIC VERSUS ACCIDENTAL HOMOPHONY. In treating syncretism as a matter for morphological theory, one is assuming that it is somehow encoded in morphological representation. However, one should also entertain the possibility that some examples may simply be due to accidental homophony. Consider the Russian data shown in Table 2. 


\begin{tabular}{lcc}
\hline & \multicolumn{2}{c}{ neuter o-stem } \\
& $\begin{array}{c}\text { stem-stress } \\
\text { 'place' }\end{array}$ & end-stress \\
& 'wine' \\
\hline NOM/ACC SG & mést[ə] & vin[ó] \\
GEN SG & mést[ə] & vin[á]
\end{tabular}

TABLE 2. Accidental homophony in Russian (partial phonetic transcription)

In an end-stressed neuter o-stem singular noun such as vino 'wine', the nominative/accusative is distinct from the genitive, while in a stem stressed noun such as mesto 'place', these forms are identical. This is due to a regular phonological rule which obtains in Russian, whereby $a$ and $o$ are distinct only under stress. At the morphological level, we can think of mesto as having the same endings as vino; the collapse of the nominative/accusative with the genitive is a superficial by-product of phonology.

However, there is good reason to believe that some syncretism is systematically encoded in the morphology. One diagnostic of systematicity is the repetition of the same pattern of syncretism across multiple inflectional affixes or rules. A familiar example is the syncretic dative/ablative plural of Latin, which is realized by two different endings, $-\bar{l} s$ and -ibus, depending on declension class. If we did not treat this as morphologically systematic, we would have to assume the chance coincidence of two instances of accidental homophony.

Another indicator of systematicity is the diachronic extension of a syncretic pattern. Again, Russian offers an example of this, illustrated in Table 3, based on Sologub (1983).

\begin{tabular}{lllll}
\hline & i-stem 'dirt' & \multicolumn{3}{c}{ a-stem 'wife' } \\
& & standard type & southern type & western type \\
\hline & & & & \\
NOM SG & grjaz'- $\varnothing$ & žen-a & žen-a & žen-a \\
ACC SG & grjaz'- $\varnothing$ & ženu & žen-u & žen-u \\
GEN SG & grjaz-i & ženy & žen-e & žen-y \\
DAT/LOC SG & grjaz-i & žen-e & žen-e & žen-y
\end{tabular}

TABLE 3. Syncretism of genitive singular with dative/locative in Russian dialects

A-stem nouns originally distinguished the genitive singular from the dative/locative (ženy 'wife' versus žene), a state of affairs still found in the standard language. However, in some southern and western dialects, these cases have fallen together, taking the form either of the original dative/locative (žene) or of the genitive (ženy). These dialect developments cannot be attributed to sound change. According to Sologub (1983: 86), this was a morphological innovation based on the pattern found in i-stem nouns such as grjaz' 'dirt', where these case forms are identical (the basis for this analogical extension was that both these declension classes are primarily feminine, while the other classes are exclusively masculine or neuter). Significantly, it was the pattern of case syncretism that was borrowed from the i-stems, and not the case form itself. ${ }^{1}$

\footnotetext{
${ }^{1}$ At least where the southern type with $-e$ is concerned. The vowels $-y[\mathrm{i}]$ and $-i[\mathrm{i}]$, though originally distinct phonemes, now function as allophonic variants, $-y$ being found after non-palatalized consonants, $-i$ elsewhere.
} 
In practice, the distinction between accidental and systematic homophony may be ambiguous or fluid. Indeed, there is diachronic evidence that originally accidental patterns can be reinterpreted as systematic. Thus, the syncretism of genitive, dative and locative singular in Russian i-stems was originally the result of regular sound change (Proto-Indo European -eis, -eyei and -ēi (Szemerényi 1989: 186-7) developed into Common Slavic -i), but later served as a template for morphological change, as shown above. ${ }^{2}$ Other examples that have been regarded as the morphological extension of originally accidental patterns include the merger of 1PL with 2SG/3SG feminine/2PL in Dhaasanac (the B forms cited below in Table 19; Sasse 1976: 219-20), 2sG/3sG present in Old Icelandic (Haugen 1982: 129, Kuryłowicz 1949 [1960: 81), 1sG/3sG present in Livonian (Kettunen (1938: 1x-lxii), and genitive singular/accusative plural in Slavic (Meillet and Vaillant 1934: 398). The examples discussed in this paper all seem to be plausible instances of systematic inflectional homophony.

3. Directionality. The mechanics of directional rules can be illustrated with a familiar example from Latin, shown in

Table 4. Nominative and accusative are syncretic in neuter nouns and distinct in masculine nouns (at least in the singular). In the singular of the second declension, the form taken by the syncretic nominative/accusative of the neuters, $-u m$, is the same as that of the distinct accusative case of the masculines.

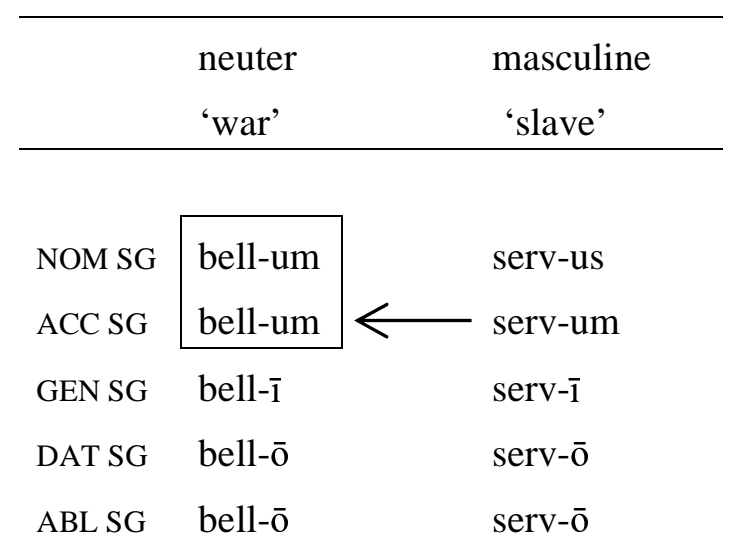

TABLE 4. Latin second declension

Thus, it looks as if the neuter nominative singular has taken the form of the accusative. Using a directional rule, this apparent 'borrowing' can be incorporated directly in the analysis. First, one can assume two general rules that apply to all second declension nouns: the nominative singular ending is -us (1a), and the accusative singular ending is -um (1b). For neuters, there is a rule stating that the nominative singular takes the form of the accusative (1c).

Thus, it might be possible to claim that the dative/locative ending of a noun like grjaz-i (where it follows a palatalized consonant) was borrowed by nouns like žen-y (where it follows a non-palatalized consonant). Even so, such an account would not work for žen-e, since this ending is not found with the i-stems.

${ }^{2}$ Alternatively, the failure to extend an originally accidental pattern may be taken as evidence that it remains unsystematic. For example, Ancient Greek had 1SG/3PL in its past active paradigm, the result of regular phonological change. This pattern was never extended, and the syncretism was ultimately disambiguated by later morphological innovations (Brian Joseph, personal communication). 

a. $\quad$ NOM SG $=$ stem + -us
b. $\quad \mathrm{ACCSG}=$ stem $+-\mathrm{um}$
c. $\quad$ NOM SG in neuter $=$ ACC SG

Because the domain of the rule in (1c) is more specific than the domain of the rule in (1a), in that it additionally contains reference to gender class, the rule in (1c) takes precedence by Pāṇini's principle. ${ }^{3}$

The morphological description above contains two rule types, one which associates a morphosyntactic value with a form (1a, b), and one which associates one morphosyntactic value with another (1c). In the terminology introduced by Zwicky (1985), the former type is a 'rule of exponence', the latter a 'rule of referral'. Rules of exponence, in some form, constitute the backbone of any morphological model - they state the association between function and form. Rules of referral, however, might be seen as secondary, since they describe a covert, morphology-internal relationship. Many observers prefer to dispense with this type of rule entirely, for reasons of formal economy.

Among the arguments against rules of referral, it is especially fitting to consider Zwicky's (2000) counterproposal, in as much as he introduced the term in the first place. He suggests that all syncretism can be described as what Stump (2001) has called symmetrical syncretism, with directional effects derived as a by-product of underspecification. I illustrate his proposal with the same Latin data from

Table 4. First, declare that nominative and accusative singular form a class, which is assigned the index ' $\mathrm{X}$ ' (2a). This class is associated with the ending -um (2b). In (2c) a more specific rule is introduced, stating that the nominative singular of the masculines has the ending - $u s$, which takes precedence over the rule in (2b) by Pānini's principle.

$$
\begin{aligned}
& \text { a. }\{\text { NOM SG } \cup \text { ACC SG }\}=X \\
& \text { b. } X=\text { stem }+ \text {-um } \\
& \text { c. } \quad \text { NOM SG in masculine }=\text { stem }+ \text {-us }
\end{aligned}
$$

Thus, under a SYMMETRICAL analysis, the specifically nominative singular masculine ending $-u s$ is opposed to the default nominative/accusative ending -um. What looks like the spread of the accusative form to the nominative is simply the emergence of the unmarked form.

This alternative analysis will work for examples of what Stump (2001) calls UNIDIRECTIONAL syncretism, that is, directional syncretism where the directional effect seems to move only in one direction (accusative $\rightarrow$ nominative in the above example). However, Stump (2001) identifies another type, BIDIRECTIONAL syncretism, where the directional effect seems to move in two directions. This does not readily lend itself to the same analysis. It is useful here to distinguish between two types, which I call convergent bidirectional syncretism and divergent bidirectional syncretism, to be defined below. Each one presents a distinct problem for Zwicky's model.

3.1 CONVERGENT BIDIRECTIONAL SYNCRETISM. Under convergent bidirectional syncretism, there is a feature value $x$ which takes the form associated with feature value $y$ in some contexts, and in other contexts takes form associated with feature value $z$. This can be illustrated by a frequently discussed example, the nominative/accusative genitive/accusative alternation of Russian. Most Russian nominal paradigms lack a distinct accusative form. Instead, it is syncretic with the genitive or with the nominative, the choice determined by the

\footnotetext{
${ }^{3}$ Pānini's principle is also familiar as the elsewhere condition, blocking and the Subset principle.
} 
interaction of word class, declension class, gender, animacy and number. I limit myself to a small fragment of the total picture; this does not affect the argument at hand (more complete analyses can be found in Corbett and Fraser (1993) and Brown (1998)). Table 5 illustrates two noun declension classes, the (masculine) o-stems and the i-stems. In the singular, the o-stems display nominative/accusative syncretism if inanimate, genitive/accusative syncretism if animate, while the i-stems display nominative/accusative syncretism, regardless of animacy. In the plural, only animacy plays a role, inanimates having nominative/accusative syncretism, animates having genitive/accusative syncretism. ${ }^{4}$

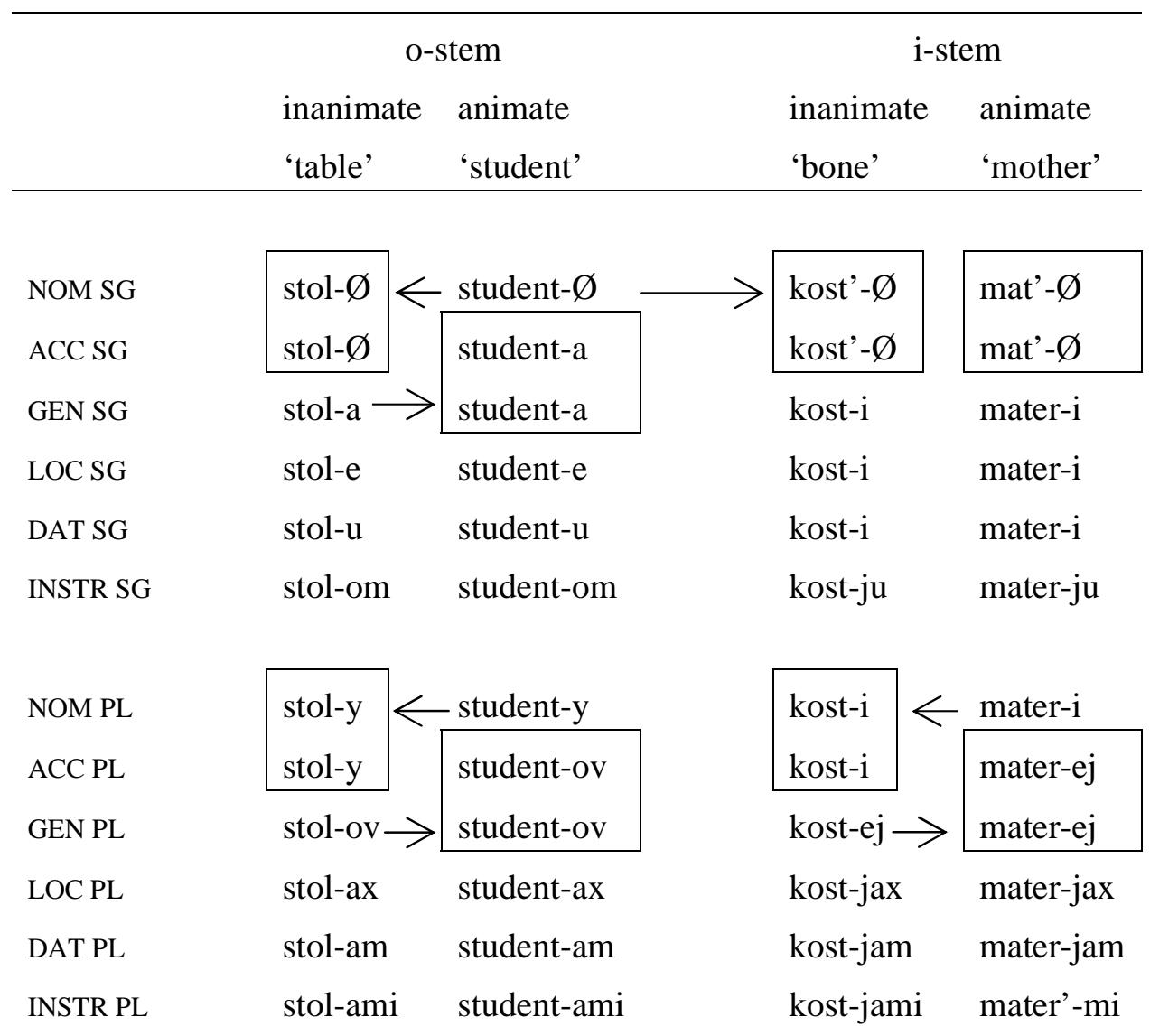

TABLE 5. A portion of Russian noun declension

Seen in directional terms, it looks as if the accusative takes the form of the genitive in some contexts, and the form of the nominative in other contexts. The following represents a possible description using directional rules. There are two rules of referral, shown in (3). By default, the accusative takes the form of the nominative (3a). With animate o-stems, and everywhere in the plural, animate accusatives take the form of the genitive (3b). The pertinent rules of exponence are shown in (4); note that no accusative forms are defined.
a. $\mathrm{ACC}=\mathrm{NOM}$
b. ACC in animate o-stem or in plural $=$ GEN

\footnotetext{
${ }^{4}$ There are two further patterns displayed by the accusative: (i) it has a distinct form, regardless of animacy (singular of a-stem nouns and feminine adjectives), and (ii) it is syncretic with the genitive, regardless of animacy (third person pronoun).
} 

a. $\mathrm{NOM} \mathrm{SG}=$ stem $+-\varnothing$
b. GEN SG in o-stem $=$ stem $+-\mathrm{a}$
c. GEN SG in $\mathrm{i}-\mathrm{stem}=\mathrm{stem}+-\mathrm{y} /-\mathrm{i}^{5}$
d. NOM PL $=$ stem $+-y /-i$
e. GEN PL in o-stem $=$ stem +- ov
f. GEN PL in i-stem $=$ stem +- ej

In order to show the result of the interaction of the rules of referral with the rules of exponence it is sufficient to look at the o-stem forms (5). In animate nouns, the rule of referral in (3a) causes the form of the genitive to be extended to the accusative, while in inanimate nouns, the rule of referral in ( $3 b$ ) causes the form of the nominative to be extended to the accusative.
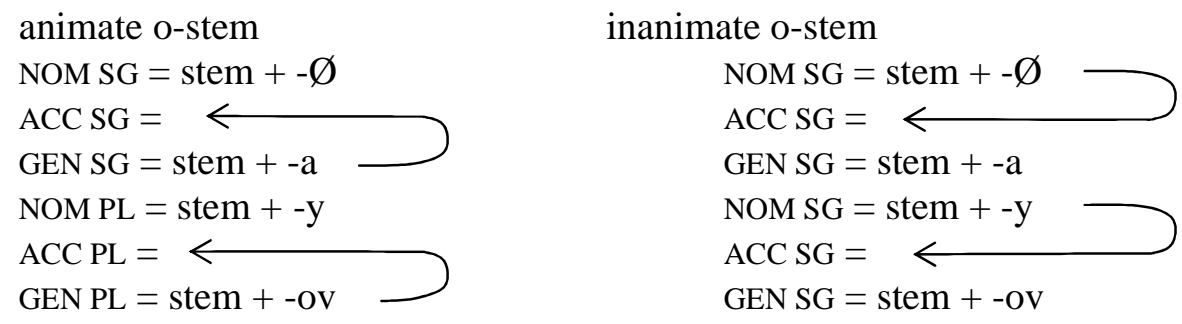

Now let us see how we might describe the same phenomenon without directional rules; as above, it is sufficient to look solely at the o-stems. First, we can convert the rules of referral in (3) into the symmetrical classes ' $\mathrm{X}$ ' and ' $\mathrm{Y}$ ' as in (6). In (7), these symmetrical rules define the syncretic forms.
a. $\{\mathrm{NOM} \cup \mathrm{ACC}\}=\mathrm{X}$
b. $\{$ GEN $\cup \mathrm{ACC}\}=\mathrm{Y}$

a. $\quad \mathrm{X} \mathrm{SG}=\mathrm{stem}+-\varnothing$

g. Y SG in o-stem $=$ stem $+-\mathrm{a}$

h. X PL $=$ stem $+-y /-i$

i. $\quad \mathrm{Y}$ PL in o-stem $=$ stem $+-\mathrm{ov}$

Obviously, this is an incomplete description, because nothing yet has been said about the contrast between animates and inanimates. Since genitive/accusative syncretism obtains only for animates, one possibility would be to include this limitation in the definition of the syncretic classes of values (8b).

revision of (6)
a. $\{\mathrm{NOM} \cup \mathrm{ACC}\}=\mathrm{X}$
b. $\{\mathrm{GEN} \cup \mathrm{ACC}\}$ in animates $=\mathrm{Y}$

These rules correctly define the animate paradigm (9a), with ' $Y$ ' taking precedence over ' $X$ ' in the accusative by Pānini's principle (since the definition of ' $Y$ ' contains overt specification for animacy, while ' $\mathrm{X}$ ' is underspecified). But the undesired consequence of limiting ' $\mathrm{Y}$ ' to animates is to deny the inanimates their genitive form ( $9 b)$.

\footnotetext{
${ }^{5}$ See footnote 1 for the variation between $-y$ and $-i$. Note that, for clarity of presentation, the syncretism between genitive singular and nominative plural is not represented in the analysis.
} 


$$
\begin{aligned}
& \text { a. animate o-stem per }(8) \\
& \text { NOM SG }=\text { stem }+-\varnothing \\
& \text { ACC SG }=\text { stem }+-\mathrm{a} \\
& \text { GEN SG }=\text { stem }+-\mathrm{a} \\
& \text { NOM PL }=\text { stem }+- \text { y } \\
& \text { ACC PL }=\text { stem }+ \text {-ov } \\
& \text { GEN PL }=\text { stem }+ \text {-ov }
\end{aligned}
$$

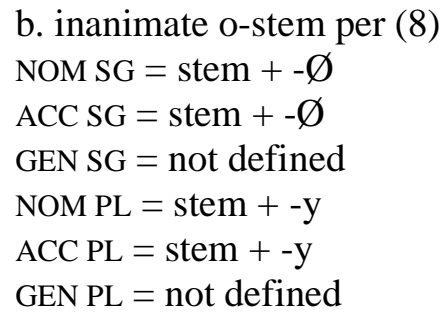

The forms associated with ' $\mathrm{X}$ ' and ' $\mathrm{Y}$ ' need to be available to both animate and inanimate paradigms, so limiting their distribution according to animacy will not work. ' $\mathrm{X}$ ' and ' $\mathrm{Y}$ ' must interact with each other in such a way that they cancel each other out only in the accusative, that is, that portion of their range where they overlap. Pānini's principle is not operative here, because neither rule is more specific than the other. The obvious option is to stipulate rule ordering, with the default ordering ' $\mathrm{X}$ ' before ' $\mathrm{Y}$ ', while animates have the ordering ' $\mathrm{Y}$ ' before ' $\mathrm{X}$ '.
a. default rule ordering
b. rule ordering for animates
i. $\mathrm{X}$
i. $Y$
ii. $Y$
ii. $\mathrm{X}$

This arrangement will produce the correct set of forms. The difficulty arises when we reflect on why we have considered this alternative analysis in the first place. Zwicky (2000) observes that a model of morphology such as Stump's (2001), which contains both symmetrical rules and directional rules, is more complex than one which contains only symmetrical rules. However, as we have just seen, a model with only symmetrical rules must also contain stipulated rule ordering to describe convergent bidirectional syncretism.

Stipulated rule ordering is itself a distinct formal device, one whose status as a component of morphology remains at least as debatable as that of directional rules. They are absent, for example, from approaches such as Stump's (2001) and Corbett and Fraser's (1993). Thus, we are left with a choice not between a more and less economical model of morphology, but between two models of equal complexity. ${ }^{6}$

3.2 FURTHER EXAMPLES OF CONVERGENT BIDIRECTIONAL SYNCRETISM. Accusative marking in Russian (and other Slavic languages) is the most familiar example of convergent bidirectional

\footnotetext{
${ }^{6}$ There is another possibility, namely to incorporate information about the lexical class within the set of syncretic values (Jonathan Bobaljik, personal communication). For example, two symmetrical rules of the shape:

$\{$ NOM $\cup$ ACC in inanimates $\}=X$

$\{$ GEN $\cup$ ACC in animates $\}=\mathrm{Y}$

would yield the correct forms, if substituted for (6).

This approach is problematic for two reasons. First, the classes indexed by $\mathrm{X}$ and $\mathrm{Y}$ contain both morphosyntactic (case) and lexical (animate nouns versus inanimate) information. It is probably fair to say that this would be an illegitimate move in most models of morphology, where one distinguishes between classes of morphosyntactic values, and classes of lexemes (e.g. word class, inflection class). Second, it is not clear that such a representation is more than a notational variant of a directional rule, in that the classes encode an obvious asymmetry. For example, ' $\{$ NOM $\cup$ ACC in inanimates $\}=X$ ' states that having form $X$ is a general property of the nominative wherever it occurs, and a contingent property of the accusative, restricted to a particular class of lexemes. In its own fashion, this suggests that form $\mathrm{X}$ is primarily a genitive form, and secondarily an accusative form.
} 
syncretism; indeed, it seems to be the only one generally discussed within the literature. However, there are other paradigms that follow this pattern, and it is worth reviewing some examples to see the variety of features that may be involved.

The Daghestanian language Lak has what could be called the ergative equivalent of the Russian pattern (see Table 6, which shows merely a fragment of the large case paradigm). Here, rather than the accusative, it is the ergative whose form varies: in nouns, it has the ending $-l$, characteristic of the distinct genitive in pronouns, while in pronouns, it has - $\varnothing$ (the bare stem), which characterizes the distinct absolutive of nouns. (Note that both nouns and pronouns may display a stem alternation between the absolutive and other cases.)

\begin{tabular}{|c|c|c|c|}
\hline & $\begin{array}{l}\text { noun } \\
\text { 'house' }\end{array}$ & & $\begin{array}{l}\text { pronoun } \\
\text { 'I' }\end{array}$ \\
\hline ABS & k'atta- $\varnothing$ & & na- $\varnothing$ \\
\hline ERG & k'atlu-1 & & na- $\varnothing$ \\
\hline GEN & k'atlu-1 & $\leftarrow$ & ttu-l \\
\hline DAT & k'atlu-n & & ttu-n \\
\hline SUPERESS & k'atlu-j & & $\mathrm{ttu}-\mathrm{j}$ \\
\hline COMIT & k'atlu-̌̌ša & & ttu-šša \\
\hline
\end{tabular}

TABLE 6. Lak declension (Žirkov 1955: 36, 64-66)

In the Mongolic language Bonan, it is the accusative case whose form varies, as in Russian, but without involving the nominative (see Table 7). In nouns, the accusative is identical to the genitive (-ne), while in pronouns, the accusative is identical to the dative-locative (-de). (Case marking in singular and plural is identical.)

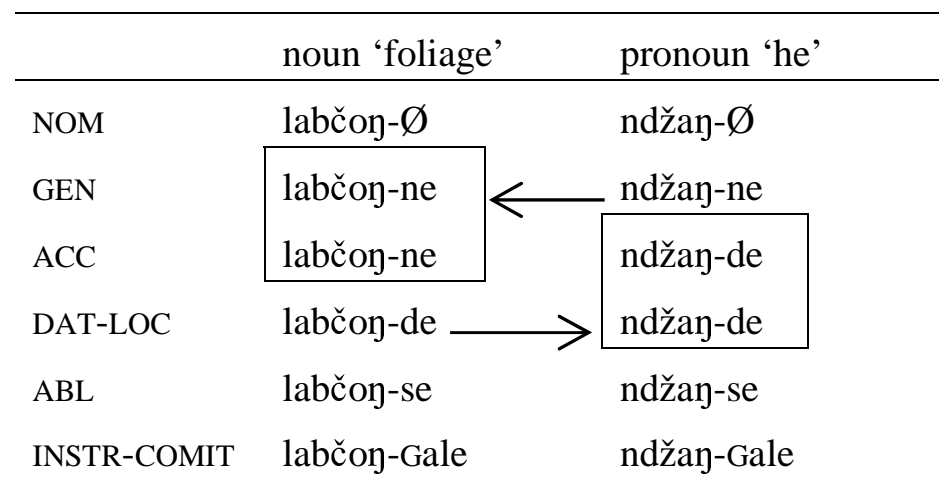

TABLE 7. Bonan declension (Todaeva 1997: 35)

In the future tense in Gujarati (see Table 8), the second person singular may take the form of the first singular $(-i \check{s})$, or it may take the form of the third person $(-\check{s} e)$. In the other tense paradigm (the neutral), second person is always syncretic with third. 


\begin{tabular}{|c|c|c|c|}
\hline & \multicolumn{2}{|c|}{ future } & \multirow[t]{2}{*}{ neutral } \\
\hline & option 1 & option 2 & \\
\hline $1 \mathrm{SG}$ & kər -iš & kər -iš & kər-ũ \\
\hline $2 \mathrm{SG}$ & kər -iš & kər -še & kər-e \\
\hline 3 & kər-še & kər -še & kər-e \\
\hline $1 \mathrm{PL}$ & kər -šs(i) & kər -̌s(i)ũ & kər-ie \\
\hline 2PL & kər -šo & kər -šo & kər-o \\
\hline
\end{tabular}

TABLE 8. Gujarati person-number conjugation (Cardona and Suthar 2003: 682, 684)

3.3 DIVERGENT BIDIRECTIONAL SYNCRETISM. As we have seen above, symmetrical rules can be used to describe convergent directional syncretism only with the aid of an additional morphological device, such as rule ordering. As for divergent bidirectional syncretism, symmetrical rules simply cannot be used to describe it in any systematic fashion. Under divergent bidirectional syncretism, there is a feature value $x$ which takes the form associated with feature value $y$ in some contexts, while in other contexts $y$ takes the form associated with $x$. For an illustration, we can return to the Latin example from

Table 4, adducing further data as shown in Table 9. In addition to the default masculine and neuter types of the second declension, there are a few nouns (the most prominent being vulgus 'crowd', vīrus, 'poison' and pelagus 'sea') which display an accusative in -us (Neue and Wagener 1902: 972). ${ }^{7}$ If we include these nouns in the picture, then the Latin second declension is not simply an example of unidirectional syncretism, but rather has two mirror-image patterns: in the default neuter type, the nominative looks like the accusative, and in the small class represented by vulgus, the accusative looks like the nominative.

\footnotetext{
${ }^{7}$ The origin of this type is mixed. Pelagus is borrowed from the Greek s-stem pelagos, where -os is the final part of the stem, and not an inflectional ending. Clearly, however, when borrowed into Latin, it was interpreted as an ending, since pelagus was assigned to the second declension (with the ending - $u s$ ), and not to the third declension s-stem type, where -us is instead the stem-final element (e.g. genus 'nation, race' and corpus 'body', where stem-final $-s$ is realized as $-r$ when followed by endings, as in the genitive singular forms gener-is, corpor-is). This justifies the treatment of the -us in pelagus and the -us in servus as representing the same ending. Other borrowings from Greek s-stems followed this pattern on occasion, such as cêtus 'large sea animal, whale' and chaus 'chaos' (Neue and Wagener 1902: 502-504). Vulgus and vìrus are native Latin items, and the origin of their exceptional declension is not known.

This type is also defective, lacking plural forms, except for the occasional pelage, whose ending is transparently Greek, unincorporated into the Latin declensional system. All of these nouns show a tendency to be reinterpreted as masculine nouns of the servus type, with nominative -us and accusative -um. One interesting variation occurs in Late Latin (sixth century), where pelagus is reinterpreted as masculine without alterning its declension pattern: the example furentem pelagus 'raging sea' (from the Variae of Cassiodorus, cited in Neue (1902: 503)) has the agreeing participle with the non-syncretic masculine accusative ending -em. This shows that nominative/accusative syncretism in the singular was not necessarily tied to neuter gender.
} 


\begin{tabular}{|c|c|c|c|c|}
\hline & $\begin{array}{l}\text { default n } \\
\text { 'war' }\end{array}$ & euter & $\begin{array}{l}\text { default masc. } \\
\text { 'slave' }\end{array}$ & $\begin{array}{l}\text { accusative in } \\
\text {-us 'crowd' }\end{array}$ \\
\hline NOM SG & bell-um & & \multirow{3}{*}{$\begin{array}{l}\text { serv-us } \longrightarrow \\
\text { serv-um } \\
\text { serv-ī }\end{array}$} & vulg-us \\
\hline ACC SG & bell-um & $\leftarrow$ & & vulg-us \\
\hline GEN SG & bell-1̄ & & & vulg- $\overline{1}$ \\
\hline DAT SG & bell-ō & & serv-ō & vulg-ō \\
\hline ABL SG & bell-ō & & serv-ō & vulg-ō \\
\hline
\end{tabular}

TABLE 9. Latin second declension

Using directional rules, this sort of pattern does not differ in principle from unidirectional syncretism. To the rules from (4) one simply adds a fourth rule (11d), stipulating that the accusative takes the form of the nominative for this small class.
a. $\quad$ NOM SG $=$ stem + -us
b. $\mathrm{ACC} S \mathrm{SG}=$ stem + -um
c. NOM SG in neuter $=$ ACC
d. ACC SG in vulgus, pelagus \& vīrus = NOM

But divergent bidirectional syncretism poses an insurmountable problem for symmetrical rules. Since both -um and - us are found with the syncretic value nominative/accusative, they must both be associated with the syncretic class of values $\{$ NOM SG $\cup$ ACC SG $\}$, or at any rate, with a class that includes these values. With the rules in (12) one can represent both the syncretic forms, where ' $\mathrm{X}$ ' stands for the $-u m$ of the neuters and ' $\mathrm{Y}$ ' stands for the $-u s$ of the vulgus type.
a. $\quad\{$ NOM SG $\cup$ ACC SG $\}=X$
b. $X$ in neuter $=$ stem + -um
c. $\{$ NOM SG $\cup$ ACC SG $\}=Y$
d. $\quad \mathrm{Y}$ in vulgus, pelagus \& vīrus $=$ stem + -us

But what about masculines, where both - us and -um are found? There is no way to include both ' $\mathrm{X}$ ' and ' $\mathrm{Y}$ ' in the same paradigm. In the Russian paradigms above, one could think in terms of rule ordering, since the domains of the two rules overlap only partially: if one rule precedes the other, the non-overlapping portion still remains active. In this case the domains of the rules overlap completely, so either ' $\mathrm{X}$ ' cancels out ' $\mathrm{Y}$ ' completely, or vice versa. On a symmetrical approach one would be forced to conclude that one of the forms in Table 9 is the result of accidental homophony; for example, by assuming two endings, nominative $-u s_{1}$ and nominative/accusative $-u s_{2}$.

3.4. FURTHER EXAMPLES OF DIVERGENT BIDIRECTIONAL SYNCRETISM. So far, the only examples which have been adduced in the literature are those found in Stump (2001), namely the genitive singular/nominative plural in Russian, the accusative/dative singular in Old Icelandic and the first singular/third plural in Romanian, which have been subject to criticism 
(Feldstein 2003, Wunderlich forthcoming). However, there are examples beyond the Latin one above which appear to be genuinely systematic.

Classical Arabic has three cases: nominative, genitive and accusative (see Table 10). In the default pattern (singulars and the broken plurals, which are formed by an alternation in the vocalic/syllabic pattern) all three cases have distinct endings: $-u,-i$ and $-a$. In the so-called sound plurals (formed by suffixation), genitive and accusative are syncretic, marked by the ending $-i$ :, which corresponds to the distinct genitive of the default type. ${ }^{8}$ Diptotic nouns (certain adjectival stems, some broken plurals and some personal names) likewise have a syncretic genitive/accusative, but the ending is $-a$, corresponding to the distinct accusative of the default type. ${ }^{9}$ The diptotic pattern is found only with indefinites; the definite form and the construct form (head of an adnominal construction) revert to the default pattern. (The dual likewise displays genitive/accusative syncretism, e.g. nominative dual, construct state mu'min-a:, genitive/accusative mu'min-ay 'believers'; these forms are distinct from those found in the singular and plural, and so do not enter into a discussion of directional effects.)

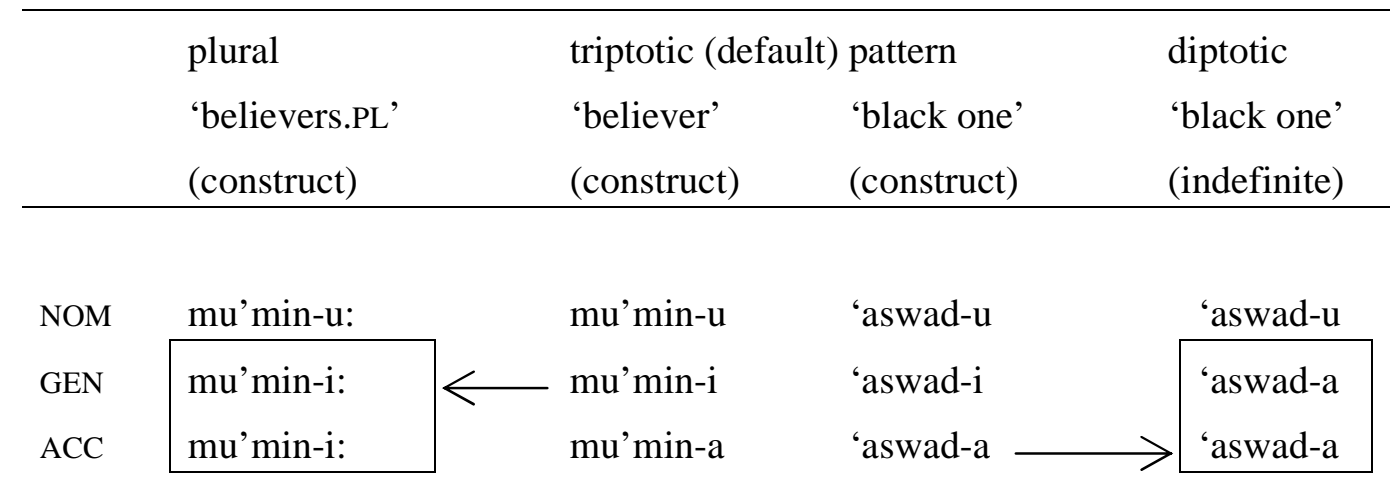

TABLE 10. Classical Arabic declension (Fischer 1997: 196)

As with the Latin example in Table 9, the analytical problem here is that, if we say that both $-i$ and $-a$ are genitive/accusative, how can the two endings be combined in a single paradigm, as occurs in the default type? Using directional rules, one could say that the accusative takes the form of the genitive in sound plurals, and that the genitive takes the form of the accusative in the diptotic type.

In the Pama-Nyungan language Diyari, dual and plural nouns and pronouns, and female personal names, have an accusative ending $-n 5 a$ which is distinct from the absolutive (see Table 11). In male personal names the ending $-n 5 a$ is found in both the absolutive and accusative. A zero ending (the bare stem) is found in the ergative/absolutive of non-singular pronouns, the ergative of non-singular nouns, and the absolutive/accusative of singular nouns.

\footnotetext{
${ }^{8}$ The singular endings are short and the plural endings long; the plural endings are assumed to derive, historically, from lengthening of the corresponding singular endings (Kienast 2001: 143).

${ }^{9}$ Altough it is not clear whether the $-a$ of the diptotic type is etymologically connected with the $-a$ of the default type, at least some observers have argued that the two have been equated with each other. Kienast (2001: 142) cites Brockelmann's (1908-13) theory that the diptotic started among personal names: some names ended in $-u$ (e.g. Iazī $u$ ) and some in - a (e.g. Šammara), and these were reinterpreted as fragments of the normal case paradigm, which was then fleshed out. Thus, this proposal assumes that the diptotic endings $-u$ and $-a$ were etymologically distinct from the corresponding case endings $-u$ and $-a$, but that at some later point a connection was drawn between the two sets.
} 


\begin{tabular}{|c|c|c|c|c|c|c|}
\hline & I & & II & III & IV & $\mathrm{V}$ \\
\hline ERG & $-(y a) l i$ & & $-\mathrm{li}$ & $-\varnothing$ & $-n d u$ & $-\mathrm{li}$ \\
\hline ABS & $-\varnothing$ & $\longleftarrow$ & $-\varnothing \longrightarrow$ & $-\varnothing$ & - ni & -na \\
\hline ACC & $-\varnothing$ & & - na & - na & - na $\longrightarrow$ & - na \\
\hline LOC & $-n i$ & & $-\mathrm{nu}$ & $-n u$ & -nanu & $-\mathrm{yu}$ \\
\hline ALL & - -уa & & $-\eta \mathrm{u}$ & $-\mathrm{ju}$ & -nayu & $-n u$ \\
\hline DAT & - -ya & & - ṇi & -ṇi & -nayka & - ṇi \\
\hline $\mathrm{ABL}$ & - ndu & & -yundu & -nundu & -nundu & -nundu \\
\hline I & \multicolumn{6}{|c|}{ singular nouns } \\
\hline II & \multicolumn{6}{|c|}{$\begin{array}{l}\text { non-singular nouns, non-singular third person pronouns, } \\
\text { singular pronouns }\end{array}$} \\
\hline III & \multicolumn{6}{|c|}{ non-singular first and second person pronouns } \\
\hline IV & \multicolumn{6}{|c|}{ female personal names, singular pronouns ${ }^{10}$} \\
\hline V & \multicolumn{6}{|c|}{ male personal names } \\
\hline
\end{tabular}

TABLE 11. Diyari declension (Austin 1981: 47-50, 61)

As with the previous examples, the problem faced by symmetrical rules is posed by the overlapping range of the endings. The zero ending ranges across all three core cases (ergative, absolutive, accusative), while $-n 5 a$ is found in both the absolutive and accusative. Using symmetrical rules, one would associate $\{$ ERG $\cup A B S \cup A C C\}$ with $-\varnothing$ and $\{A B S \cup A C C\}$ with $-n 5 a$. Since the two rules overlap completely, they cannot be made to coexist within the same paradigm, as occurs in type II. Again, directional rules are the only device that can give $-\varnothing$ and $-n 5 a$ a unified representation across all of the paradigms. One possible analysis is to identify $-\varnothing$ as the absolutive ending and $-n 5 a$ as the accusative ending. In type I, the accusative takes the form of the absolutive, in type III, the ergative takes the form of the absolutive, and in type $\mathrm{V}$, the absolutive takes the form of the accusative. ${ }^{11}$ (In type IV a distinct absolutive ending is found.)

3.5 SYMMETRICAL VERSUS DIRECTIONAL RULES: A SUMMARY. Zwicky (2000) has argued that symmetrical rules are sufficient to generate the surface effect of directionality, thus making directional rules unnecessary. However, we have seen that the rejection of directional rules brings real consequences in the range of facts that can be described (further arguments may be found in Evans et al. 2001, using somewhat different evidence). Although symmetrical

\footnotetext{
${ }^{10}$ Singular pronouns, besides the third person non-feminine, display this pattern in the ergative, absolutive and accusative, while in the remaining cases they behave like non-singular pronouns, with the element $-k a-$ preceding the endings. The third person non-feminine behaves essentially like a non-singular noun, with ergative $\underline{n} u l u$, absolutive $\underline{n} a w u$, accusative $\underline{n} \underline{\operatorname{n}} \underline{\mathrm{n}} a$, and remaining cases based on the stem $\underline{\mathrm{n}} u \eta k a-$ (Austin 1981: 61).

${ }^{11}$ A plausible alternative in this case would be to combine symmetrical and directional rules by viewing $-\varnothing$ as the default core case ending. Types I-IV then follow a familiar split ergative accusative pattern, with a distinct ergative in some paradigms and a distinct accusative in others. In this case, only type $\mathrm{V}$ requires a directional rule. In either case, though, directional rules are required.
} 
rules can describe unidirectional syncretism, convergent directional syncretism can only be described by substituting another formal device (rule ordering), thus weakening the argument that symmetrical rules entail greater formal economy. Divergent bidirectional syncretism cannot be described at all with symmetrical rules.

More importantly, perhaps, the difference between symmetrical and directional rules may be more superficial than has been claimed. With minimal alteration, the formalism used to describe symmetrical rules can be used to induce directionality. Consider the symmetrical analysis of the Latin second declension given in (2), reproduced below as (13a-c). In the revised version in (13a'-c'), all references to the index ' $X$ ' have been removed, and the ending -um is associated instead with the accusative singular.

$$
\begin{aligned}
& \text { a. }\{\text { NOM SG } \cup \text { ACC SG }\}=X \\
& \text { b. } X=\text { stem }+ \text {-um } \\
& \text { c. NOM SG in masculine }=\text { stem }+ \text {-us }
\end{aligned}
$$

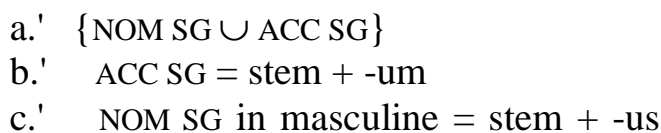

The rules in (13b'-c') yield forms for all but the nominative singular of neuters, which remains undefined. However, in (13a') it is stipulated that nominative and accusative singular form a class, with the understanding that any rule that applies to the one value applies to the other as well, all else being equal. Although the neuter nominative is undefined, (13a') states that it will behave in the same way as the accusative. The one assumption that must be made here is that a defined form will take precedence over an undefined form. Thus, a rule of referral, or its equivalent, is induced where a paradigmatic gap falls within a defined class of values. If one accepts this view of the underlying motivation for rules of referral, this strengthens the case that symmetrical rules do not entail greater formal economy than directional rules.

3.6 RANKED CONSTRAINTS AS AN ALTERNATIVE TO DIRECTIONAL SYNCRETISM. Alongside Zwicky's (2000) discussion, the argument that directional effects can be derived without using directional rules has come from the perspective of Optimality Theory (OT). The issue is addressed most directly by Wunderlich (forthcoming), who offers an OT alternative to directional rules. Most relevant is his treatment of what I have termed convergent syncretism, for which he analyses the nominative/accusative $\sim$ genitive/accusative alternation of Russian. For the present purposes, it is sufficient to consider case alternation in the singular of o-stems and $i$-stems, as shown in Table 5 above. The feature values he proposes for the morphosyntactic cases is given in (14). The nominative is simply unmarked. The other cases are rendered in terms of semantic roles: the accusative is $\left[(+\mathrm{hr})_{\mathrm{v}}\right]$ ("there is a higher role (verbal)'), which expresses its subordinate role within a transitive verbal clause, while the genitive is $\left[(+\mathrm{hr})_{\mathrm{N}}\right]$ ('there is a higher role (nominal)'), which expresses its subordinate role

\begin{tabular}{|c|c|c|}
\hline case name & feature value & \\
\hline nominative & & \\
\hline accusative & {$\left[(+h r)_{v}\right]$} & i.e. 'there is a higher role (verbal)' \\
\hline genitive & {$\left[(+\mathrm{hr})_{\mathrm{N}}\right]$} & i.e. 'there is a higher role (nominal) \\
\hline
\end{tabular}
within a nominal clause.

The relevant case endings are given in (15). The i-stem genitive $-i$ is fully specified in terms of the underlying morphosyntactic features. The o-stem ending $-a$ is underspecified: the value $[(+h r)]$, which omits reference to nominal or verbal contexts, represents genitive/accusative syncretically as a natural class. The default ending $-\varnothing$ has no feature specifications. 
$(15)$

\begin{tabular}{ll}
\multicolumn{2}{c}{ o-stem } \\
ending & feature value \\
$-\varnothing$ & {$[\mathrm{]}$} \\
$-\mathrm{a}$ & {$[(+\mathrm{hr})]$}
\end{tabular}

\begin{tabular}{ll}
\multicolumn{2}{c}{ i-stem } \\
ending & feature value \\
$-\varnothing$ & {$[\mathrm{]}$} \\
$-\mathrm{i}$ & {$\left[(+\mathrm{hr})_{\mathrm{N}}\right]$}
\end{tabular}

The link between the underlying morphosyntactic features and the endings is effected by three ranked constraints:

- Compatibility: the categorical specification of input and output must match. That is, genitive case (with a nominal specification) cannot be used where the input requires accusative case (with a verbal specification), and vice versa.

- $*(+\mathrm{hr}) / \mathrm{v}$ inanimate: do not mark accusative case for inanimates.

- Max (+hr): if the feature (+hr), common to the accusative and genitive, is present in the input, it must be realized in the output.

The interaction of the above elements is shown in the tableaux in Table 12-Table 14. In animate o-stems, the constraint Max (+hr) blocks the ending $-\varnothing$, because it is not specified for $(+h r)$, thus causing the genitive/accusative to be selected. In the inanimate o-stems, however, the genitive/accusative is blocked by the constraint $*(+h r) / \mathrm{v}$ inanimate, so the unmarked nominative is selected, in spite of its violation of Max $(+\mathrm{hr})$. In the animate i-stems, Compatibility blocks the use of the overtly genitive ending $-i$ for the input accusative, so the nominative is selected; the issue of animacy does not even arise. ${ }^{12}$

\begin{tabular}{|c|l|l|l|}
\hline input: $\left[(+\mathrm{hr})_{\mathrm{v}}\right]$, animate & Compatibility & $\begin{array}{l}*(+\mathrm{hr}) / \mathrm{v} \\
\text { inanimate }\end{array}$ & Max $(+\mathrm{hr})$ \\
\hline student- $\varnothing[\mathrm{C}]$ & & & $* !$ \\
\hline student-a $[(+\mathrm{hr})]$ & & & \\
\hline
\end{tabular}

TABLE 12. Accusative of animate o-stem

\begin{tabular}{|l|l|l|l|}
\hline input: $\left[(+\mathrm{hr})_{\mathrm{v}}\right]$, inanimate & Compatibility & $\begin{array}{l}*(+\mathrm{hr}) / \mathrm{v} \\
\text { inanimate }\end{array}$ & Max $(+\mathrm{hr})$ \\
\hline stol $[\mathrm{]}$ & & & $*$ \\
\hline stol-a $[(+\mathrm{hr})]$ & & $* !$ & \\
\hline
\end{tabular}

TABLE 13. Accusative of inanimate o-stem

\footnotetext{
${ }^{12}$ Note that this analysis only addresses the distribution of the endings, while the stem alternation between mat'- and mater'- (see Table 5) remains unaccounted for. Since the stem mater'- is not overtly genitive, it does not violate Compatibility, so it is not clear what prevents an accusative form such as *mater'- $\emptyset$.
} 


\begin{tabular}{|c|l|l|l|}
\hline input: $\left[(+\mathrm{hr})_{\mathrm{v}}\right]$, animate & Compatibility & $\begin{array}{l}*(+\mathrm{hr}) / \mathrm{v} \\
\text { inanimate }\end{array}$ & Max $(+\mathrm{hr})$ \\
\hline mat $\quad[]$ & & & $*$ \\
\hline mater-i $\left[(+\mathrm{hr})_{\mathrm{N}}\right]$ & $* !$ & & \\
\hline
\end{tabular}

TABLE 14. Accusative of animate i-stem

To the extent that the factual coverage is the same, the choice between this analysis and one which employs directional rules (e.g. Corbett and Fraser 1993) only has significance within the context of the theoretical and descriptive program of the individual investigator. ${ }^{13}$ I limit myself to assessing its formal properties. In effect, the analysis involves symmetrical rules plus rule ordering, as sketched above in (10); in this case, constraint ranking is the equivalent of rule ordering. The combination of lexical specifications and constraints state, in effect, that a rule for genitive/accusative precedes a rule for nominative/accusative. Under certain conditions the genitive/accusative rule is blocked, allowing the nominative/accusative rule to be first. Naturally, such a model can easily describe unidirectional syncretism as well. But, as I suggest above, it cannot describe divergent bidirectional syncretism. Wunderlich raises the issue but does not propose an analysis, instead rejecting one of Stump's (2001) examples of divergent bidirectional syncretism. However, other examples could be offered in its place (as

\footnotetext{
${ }^{13}$ Wunderlich's (forthcoming) analysis of Russian is part of a larger model of the differential marking of objects and agents, whereby arguments high on the animacy/prominence scale tend to mark the accusative, and arguments low on this scale tend to mark the ergative. Whatever the cross-linguistic insights of this approach, it fails to capture some fairly striking generalizations that obtain within the languages actually under analysis. In the Russian example, the genitive/accusative syncretism displayed by the animate accusative is attributed to underspecification of the ending, so it is, in effect, a lexical idiosyncrasy. But it is not just one ending which needs to be underspecified, but rather seven (the four seen in Table 5, which are treated by Wunderlich, plus three distinct adjectival and pronominal endings). This is why the animate accusative in Russian and other Slavic languages has long been used as an example of systematic syncretism, and particularly of directional rules (starting with Perlmutter and Orešnik 1973). The alternative as offered by Wunderlich is to treat the sevenfold repetition of this pattern as purely accidental

A similar atomization results when we consider another of his proposals, namely that the constraint $*(+h r) / \mathrm{V}$ inanimate can generally be used to account for the nominative/accusative syncretism typical of Indo-European languages. Recall that this constraint blocks the use of the accusative ending for inanimates ( $\approx$ neuters), which instead use the default form (informally, the nominative). But consider Latin once again. It is true that this analysis is possible for the singular of some nouns of the third declension. The nominative singular of masculines is the bare stem, and the accusative is the stem plus -em. In neuters, the nominative/accusative is the bare stem, which could easily be described as the result of the omission of the accusative ending.
}

\begin{tabular}{lll} 
& \multicolumn{1}{c}{$\begin{array}{c}\text { masculine } \\
\text { 'conqueror' }\end{array}$} & \multicolumn{1}{c}{$\begin{array}{c}\text { neuter } \\
\text { 'sea' }\end{array}$} \\
NOM & victor- $\varnothing$ & aequor- $\varnothing$ \\
ACC & victor-em & aequor- $\varnothing$ \\
GEN & victor-is & aequor-is \\
DAT & victor-1 & aequor-i \\
ABL & victor-e & aequor-e
\end{tabular}

But such an analysis cannot be applied to the second declension nouns described above in Table 4. The neuter is distinguished from the masculine by the lack of the NOMINATIVE singular ending -us. Undoubtedly, this could be accounted for by some constraint, but, equally undoubtedly, this is not the same constraint $*(+\mathrm{hr}) / \mathrm{V}$ inanimate found in the third declension, which blocks the accusative. Thus, the observation that neuter nouns in Latin have nominative/accusative syncretism is reduced to the concatenation of two apparently unrelated facts. 
in $\S 3.4$ above). Thus, the empirical problem created by divergent bidirectional syncretism remains.

However, the difficulty caused by rejecting directional rules is not really a problem for Wunderlich's model, since it in fact contains all the material needed to produce them, even though this is not directly exploited. To demonstrate this, let us review some of the key points in the above analysis. The core of the morphological model consists of three elements: the input (the morphosyntactic feature value), the output (the inflectional ending itself) and the Max constraint which mediates between them. In the accusative, the input is fully specified (accusative, i.e. $\left[(+\mathrm{hr})_{\mathrm{v}}\right]$ ), while the Max constraint is underspecified (genitive/accusative, i.e. $(+\mathrm{hr})$ ). The behavior of the output form varies: in o-stems it is treated as underspecified, in $\mathrm{i}$-stems it is treated as fully specified, as shown in (16).

$\begin{array}{ll} & \text { o-stems } \\ \text { input } & {\left[(+\mathrm{hr})_{\mathrm{V}}\right] \text { is fully specified }} \\ \text { output } & {[(+\mathrm{hr})] \text { is underspecified }} \\ \text { Max } & (+\mathrm{hr}) \text { is underspecified }\end{array}$

i-stems

$\left[(+h r)_{v}\right]$ is fully specified

$\left[(+\mathrm{hr})_{\mathrm{v}}\right]$ is fully specified

$(+\mathrm{hr}) \quad$ is underspecified

However, this variation in the lexical specification of the output forms makes no difference in the selection of the winning candidate. Both the underspecified output and the fully specified output satisfy the underspecified Max constraint. Depending on whether the output is underspecified or fully specified, the syncretism found in the animate accusative will be portrayed as symmetrical or directional. This is illustrated in Table 15- Table 16, which generically represent the animate accusative. The tableau in Table 15 represents symmetrical syncretism as effected through an underspecified output: there is a syncretic genitive/accusative form, which can be used for the accusative (this corresponds to the way the tableaux in Table 12Table 13 work). The tableau in Table 16 represents directional syncretism as effected through a fully specified output: the genitive form can be used for the accusative (this corresponds to the way the tableau in Table 14 works).

\begin{tabular}{|c|l|}
\hline input: ACC $\left[(+\mathrm{hr})_{\mathrm{v}}\right]$ & Max $(+\mathrm{hr})$ \\
\hline NOM [ ] & $* !$ \\
\hline GEN/ACC $[(+\mathrm{hr})]$ & \\
\hline
\end{tabular}

TABLE 15. Tableau with underspecified output

\begin{tabular}{|c|l|}
\hline input: ACC $\left[(+\mathrm{hr})_{\mathrm{v}}\right]$ & Max $(+\mathrm{hr})$ \\
\hline NOM [] & $* !$ \\
\hline GEN $\left[(+\mathrm{hr})_{\mathrm{N}}\right]$ & \\
\hline
\end{tabular}

TABLE 16. Tableau with fully specified output

In effect, the tableau in Table 16 is the OT equivalent of the directional model outlined above in (13): the Max constraint defines the syncretic class of values, while the absence of a distinct accusative in the output produces the paradigmatic gap. The effects of this directional rule do not surface in Wunderlich's analysis because they are blocked by a higher ranking constraint (Compatibility), which bars the use of the genitive for the accusative. But directional rules are nonetheless built into the analysis, and indeed are implied wherever a fully-specified output interacts with an underspecified Max constraint. Thus, Wunderlich's 
model cannot be seen as offering an alternative to directional rules, because it already contains them.

4. (UN)NATURAL CLASSES. It is often assumed that syncretism can be taken to reflect natural classes of feature values. Jakobson (1936) was the first to formalize this view, which was then adapted to generative grammar by Bierwisch (1967); more recent treatments include Calabrese (1998), Noyer (1997, 1998) and Müller (forthcoming).

As an example of such an approach, we might take the Gujarati paradigm given in Table 8, and analyze the person values in terms of component subvalues which define natural classes.

$\begin{array}{ll}\text { feature value } & \text { underlying subvalues } \\ \text { first person } & {[+1,-3]} \\ \text { second person } & {[-1,-3]} \\ \text { third person } & {[-1,+3]}\end{array}$

We could then characterize the first/second and second/third person syncretism as reflecting the underlying structure of the feature 'person'. First/second person syncretism is [-3] (which we could give some name such as 'discourse participant'), while second/third person syncretism is [-1] (which we might call 'non-speaker'). This would free us of the need to stipulate which values are syncretic. Whatever the purely formal advantages of such an approach, the most important question is whether it can account for all the relevant data. Unfortunately, this is not a question that can be easily assessed in general terms. Wildly different models of feature structure are in circulation, which differ not only in their structural properties, but also in the repertoire of feature values they employ. Each makes different predictions, and I do not propose to survey them. ${ }^{14}$ It is sufficient to show two examples of syncretic patterns which are clearly systematic, and which involve morphosyntactic values so remote from each other that any account in terms of natural classes would void the notion of any explanatory value.

Hansson (1996) describes syncretism of the comitative singular and locative plural in North Sami. In the more conservative Western Finnmark dialects, this pattern is found in nouns only (Table 17), while pronouns have two distinct forms (Table 18). However, in the Eastern Finnmark dialects, this syncretic pattern has been extended to pronouns as well, through extension of the comitative singular form to the locative plural.

\footnotetext{
${ }^{14}$ Support for the validity of a particular model of feature structure, and for such an approach in general, might be found if they yielded valid cross-linguistic generalizations. The only attempt I am aware of to do so against a controlled sample of languages is Harley and Ritter (2002). These predictions do not appear to be borne out (for details, see Baerman (forthcoming)).
} 


\begin{tabular}{lll}
\hline & \multicolumn{1}{l}{ SG } & \multicolumn{1}{l}{ PL } \\
\hline NOM & čalbmi & čalmmi-t \\
ACC/GEN & čalmmi & čalmmi-id \\
ILL & čalbmá-i & čalmmi-de \\
LOC & čalmmi-s & čalmmi-in \\
COM & čalmmi-in & čalmmi-iguin \\
ESS & čalbmi-n & čalbmi-n
\end{tabular}

TABLE 17. North Sami noun declension, ‘eye’ (Hansson 1996: 15)

\begin{tabular}{lllll}
\hline & \multicolumn{2}{l}{ Western Finnmark } & \multicolumn{2}{l}{ Eastern Finnmark } \\
& SG & PL & SG & PL \\
\hline NOM & gii & gea-t & gii & gea-t \\
ACC/GEN & gea-n & gea-id & gea-n & gea-id \\
ILL & gea-sa & gea-idda & gea-sa & gea-idda \\
LOC & gea-s & gea-in & gea-s & gea-inna \\
COM & gea-inna & gea-iguin & gea-inna & gea-iguin \\
ESS & gea-nin & gea-nin & gea-nin & gea-nin
\end{tabular}

TABLE 18. North Sami pronoun declension, ‘who’ (Hansson 1996: 16)

This morphological innovation demonstrates that comitative singular/locative plural syncretism is systematic in the Eastern Finnmark dialects, at least at the moment the change occurred. It is unlikely that any model of feature structure could plausibly represent these two paradigmatic cells as being a natural class. The one option would be to treat -inna as a fully underspecified ending, which could be inserted in any paradigmatic cell. However, there are no independent reasons to believe that -inna is the default case-number ending.

The Cushitic language Dhaasanac displays a complex pattern of person and number syncretism in its verbal subject person markers, described by Tosco (2001: 123-206). In the tense/aspect paradigms where person is marked (the perfect and imperfect positive, the dependent positive and the short past) there are two distinct forms, which Tosco (2001) labels 'A' and 'B', following Sasse (1976). The A form is used for the first person singular, third person singular masculine, first person inclusive plural and the third person plural, while form $\mathrm{B}$ is used for the second person in both numbers, third person singular feminine and the first person exclusive plural (see Table 19a). The contrast between the A and B forms is illustrated in Table 19b. It takes a number of different shapes, depending on the verb stem, involving stem-final (a-e) or stem-initial (f) consonant alternations and vowel insertion (c) and alternation (d-e). 


\begin{tabular}{lll}
\hline a. & SG & PL \\
\hline 1INCL & ---- & A \\
\cline { 3 - 3 } 1EXCL & A & B \\
2 & B \\
\cline { 2 - 3 } $3 \mathrm{~F}$ & B \\
\cline { 3 - 3 } $3 \mathrm{M}$ & $\mathrm{A}$ & $\mathrm{A}$ \\
& & $\mathrm{A}$
\end{tabular}

a. Dhaasanac verb paradigm

\begin{tabular}{|c|c|c|}
\hline b. $\quad A$ & B & \\
\hline a. lee $\Delta \mathrm{i}$ & leeti & 'fall down.PERF' \\
\hline b. kufi & kuyyi & 'die.PERF' \\
\hline c. guurma & guuranna & 'migrate.IMPERF \\
\hline d. ?uufumi & ?uufeeni & 'cough.PERF' \\
\hline e. $\operatorname{se} \Delta$ & sieti & ‘walk.PERF' \\
\hline f. yes & ces & 'kill.PERF' \\
\hline
\end{tabular}

b. examples of $\mathrm{A} \sim \mathrm{B}$ alternation

TABLE 19

The variety of morphological processes associated with the $\mathrm{A} \sim \mathrm{B}$ alternation leaves little doubt as to its systematicity, but how can we characterize the sets of person/number/gender values that the two forms encode? Part of the problem might be circumvented by construing the A form (which Tosco treats as the morphological base) as completely underspecified for agreement features. But the B form must still be accounted for, and there is no plausible model of person-number-gender features that would unite these values as a natural class.

These examples show the need for unnatural (morphologically stipulated) classes of morphosyntactic values. This is not an argument against natural classes as such. However, once unnatural classes are admitted, they can freely substitute for natural classes. That being the case, the choice between one or the other interpretation becomes a matter of personal preference, thereby weakening the notion that natural classes impose any necessary constraints on morphological behavior.

4. CONCLUSION. Directional rules and unnatural classes are problematic notions within linguistics, since they involve the overt stipulation of relationships between morphological objects, relationships which are independent of the morphosyntactic function that underlies them. The rejection of these concepts is motivated by the desire for a simpler model of grammar, the argument being that they make no significant contribution to the range of facts that can be described. However, they do, as the examples above show. The purpose of the present paper has been to demonstrate that these and similar examples should be allowed to inform our model of morphology. This is not to claim that all apparent instances of syncretism must necessarily be treated as morphologically systematic, but rather that such an interpretation should always be available, to be considered on its individual merits rather than excluded a priori. A formal model which instead dismisses certain phenomena from the outset can only be a poor representation of linguistic reality.

Do these considerations mean that we require three distinct devices (natural classes, unnatural classes and directional rules) to describe syncretism, as argued by Stump (2001)? The more pertinent question might well be: can we avoid these three devices? In $\$ 3.5$ and $\$ 3.6$ I argued that a model which allows classes of morphosyntactic values already contains the necessary material for generating directional rules. In $\S 4$ I argued that unnatural classes of values must be allowed, thus making the notion of natural classes optional. Nevertheless, natural classes of some sort are convenient and attractive, and it is unlikely that many linguists would want to dispense with them completely. Nor can they be said to do any harm. This leads us back to Stump's (2001) three devices for describing syncretism, or some 
notional equivalent thereof (for example, the constraint-based approach of Wunderlich (forthcoming)). The syncretic patterns we have looked at here suggest that morphological structure is, at least in some degree, independent of meaning, as argued by Aronoff (1994), Corbett and Fraser (1993) and Stump (2001), among others.

\section{REFERENCES}

Anttila , Raimo. 1972. An introduction to historical and comparative linguistics. New York: Macmillan.

Aronoff, Mark. 1994. Morphology by itself. Cambridge: MIT Press.

Austin, Peter. 1981. A grammar of Diyari, South Australia. Cambridge: Cambridge University Press.

Baerman, Matthew. 2002. Syncretism: an annotated bibliography. Available online at http://www.surrey.ac.uk/LIS/MB/Bibliography.htm.

Baerman, Matthew. Forthcoming. Typology and the formal modelling of syncretism. Yearbook of Morphology 2004, ed. by Geert Booij and Jaap van Marle. Dordrecht: Kluwer.

Baerman, Matthew and Dunstan Brown. In press a. Case syncretism. In Haspelmath et al.

Baerman, Matthew and Dunstan Brown. In press b. Verbal person/number syncretism. In Haspelmath et al.

Bierwisch, Manfred. 1967. Syntactic features in morphology: general problems of so-called pronominal inflection in German. To honor Roman Jakobson: essays on the occasion of his seventieth birthday, 239-270. The Hague: Mouton.

Bobaljik, Jonathan. 2002. Syncretism without paradigms: Remarks on Williams 1981, 1994. Yearbook of Morphology 2001, ed. by Geert Booij and Jaap van Marle, 53-86. Dordrecht: Kluwer.

Brockelmann, Carl. 1908-13. Grundriss der vergleichenden Grammatik der semitischen Sprachen. Berlin: Reuther \& Reichard.

Brown, Dunstan. 1998. From the general to the exceptional: A Network Morphology account of Russian nominal inflection. Guildford: University of Surrey dissertation.

Calabrese, Andrea. 1998. Some remarks on the Latin case system and its development in Romance. Theoretical analyses on Romance languages, ed. by José Lema and Esthela Treviño, 71-126. Amsterdam and Philadelphia: John Benjamins.

Carstairs, Andrew. 1987. Allomorphy in inflection. London: Croom Helm.

Carstairs-McCarthy, Andrew. 1998. Comments on the paper by Noyer. In Lapointe et al., 286-301.

Corbett, Greville and Norman Fraser. 1993. Network morphology: a DATR account of Russian nominal inflection. Journal of Linguistics 29.113-42.

Cordona, George and Babu Suthar. 2003. Gujarati. The Indo-Aryan languages, ed. by George Cardona and Dhanesh Jain, 658-97. London: Routledge.

Martin Haspelmath, Dryer, Matthew, David Gil and Bernard Comrie (eds.) in press. World atlas of language structures. Oxford: Oxford University Press.

Evans, Nicholas, Dunstan Brown and Greville Corbett. 2001. Dalabon pronominal prefixes and the typology of syncretism: a Network Morphology analysis. Yearbook of Morphology 2000, ed. by Geert Booij and Jaap van Marle, 187-231. Dordrecht: Kluwer.

Feldstein, Ronald. 2003. On the structure of syncretism in Romanian conjugation.

Bloomington: Indiana University, ms. 
Fischer, Wolfdietrich. 1997. Classical Arabic. The Semitic languages, ed. by Robert Hetzron, 187-219. London: Routledge.

Hansson, Gunnar. 1996. Productive syncretism and morphological theory: a case study of North Sami inflectional morphology. Berkeley: University of California, ms.

Harley, Heidi and Elizabeth Ritter. 2002. Person and number in pronouns: a feature-geometric analysis. Language 78.482-526.

Haugen, Einar. 1982. Scandinavian language structures: a comparative historical survey. Minneapolis: University of Minnesota Press.

Jakobson, Roman O. 1936. Travaux du Cercle Linguistique de Prague VI.240-299.

Kachru, Braj. 1969. A reference grammar of Kashmiri. Urbana: Dept. of Linguistics, University of Illinois.

Kettunen, Lauri. 1938. Livisches Wörterbuch mit grammatischer Einleitung. Helsinki: Suomalais Ugrilainen Seura.

Kienast, Burkhart. 2001. Historische semitische Sprachwissenschaft. Wiesbaden: Harrassowitz.

Kuryłowicz, Jerzy. 1949 [1960]. De la nature des procès dits 'analogiques'. Reprinted in Esquisses linguistiques, 66-86. Wrocław: Zakład narodowy im. Ossolińskich.

Lapointe, Steven, Diane Brentari and Patrick Farrell (eds.) 1998. Morphology and its relation to phonology and syntax. Stanford: CSLI Publications.

Meillet, Paul and André Vaillant. 1934. Le Slave commun. Paris: Institut d'études slaves.

Müller, Gereon. Forthcoming. A Distributed Morphology approach to syncretism in Russian noun inflection. Proceedings of Formal Approaches to Slavic Linguistics 12, ed. by Olga Arnaudova, Wayles Browne, Maria Luisa Rivero and Dejan Stojanović. Ann Arbor: Michigan Slavic Publications.

Neue, Friedrich and C. Wagener. 1902. Formenlehre der lateinischen Sprache (Volume 1: Das Substantivum). Leipzig: O. R. Reisland.

Noyer, Rolf. 1997. Features, positions and affixes in autonomous morphological structure. New York and London: Garland.

Noyer, Rolf. 1998. Impoverishment theory and morphosyntactic markedness. In Lapointe et al., 264-85.

Perlmutter, David and Janez Orešnik. 1973. Language-particular rules and explanation in syntax. A Festschrift for Morris Halle, ed. by Steven Anderson and Paul Kiparsky, 419-59. New York: Holt Rinehart

Sasse, Hans-Jürgen. 1976. Dasenech. The non-Semitic languages of Ethiopia, ed. by M. Lionel Bender, 196-221. East Lansing: African Studies Center, Michigan State University.

Sologub, A. I. 1983. O sinkretizme form v sklonenii suščestvitel'nyx ženskogo roda edinstvennogo čisla po dialektnym dannym. Russkie narodnye govory, ed. by Ruben I. Avanesov, 82-88. Moscow: Nauka.

Stump, Gregory. 1993. On rules of referral. Language 69.449-479.

Stump, Gregory. 2001. Inflectional morphology. Cambridge: Cambridge University Press.

Szemerényi, Oswald. 1989. Einführung in die vergleichende Sprachwissenchaft. Darmstadt: Wissenshaftliche Buchgesellschaft.

Todaeva, Buljaš X. 1997. Baoan'skij jazyk. Jazyki mira: mongol'skie jazyki, tunguso-man'čžurskie jazyki, japonskij jazyk, korejskij jazyk, ed. by V. M. Alpatov, I. V. Kormušin, G. C. Pjurbeev and O. I. Romanova, 29-36. Moscow: Indrik.

Tosco, Mauro. 2001. The Dhaasanac language. Köln: Köppe.

Wunderlich, Dieter. Forthcoming. Is there any need for the concept of directional syncretism? Explorations in nominal inflection, ed. by Lutz Gunkel, Gereon Müller and Gisela Zifonun. Berlin: Mouton de Gruyter. 
Zwicky, Arnold. 1985. How to describe inflection. Berkeley Linguistics Society 11.372-386.

Zwicky, Arnold. 2000. Describing syncretism: rules of referral after fifteen years. Paper presented at the annual meeting of the Berkeley Linguistics Society, University of California, Berkeley.

Linguistic, Cultural and International Studies

University of Surrey

Guildford, Surrey GU2 7XH

United Kingdom

[m.baerman@surrey.ac.uk] 